\title{
Ubuntu and philoxenia: Ubuntu and Christian worldviews as responses to xenophobia
}

Author:
Mojalefa L.J. Koenane ${ }^{1}$
Affiliation:
1'Department of Philosophy,
Practical and Systematic
Theology, University of
South Africa, South Africa
Corresponding author:
Mojalefa Koenane,
koenamlj@unisa.ac.za
Dates:
Received: 23 May 2017
Accepted: 17 Nov. 2017
Published: 10 Apr. 2018
How to cite this article:
Koenane, M.L.J., 2018,
'Ubuntu and philoxenia:
Ubuntu and Christian
worldviews as responses to
to read online.
xenophobia', HTS Teologiese
Studies/Theological Studies
74(1), 4668. https://doi.
org/10.4102/hts.v74i1.4668
Copyright:
(c)
2018. The Authors.
Licensee: AOSIS. This work
is licensed under the
Creative Commons
Attribution License.

Xenophobic attitudes and violence have become regular phenomena in South Africa and other parts of the world. Xenophobia is of great concern not only to South Africans, but also to most developed countries or countries that are considered economically and politically viable by their neighbours, and which offer a safe haven for people who, for whatever reason, are forced to seek refuge elsewhere. Although xenophobia is not unique to South Africa, its most worrying aspect in South Africa is the government's inability to deal with this evil. The article seeks to challenge South Africa as a dominantly Ubuntu and Judeo-Christian influenced country to fight xenophobia through appealing to Ubuntu values and philoxenia. By Judeo-Christian, I mean religious beliefs and values that are common to both these religions, namely Judaism and Christianity. The article further suggests the ontology that perceives the 'other' as an extension of the self. It is argued that South African citizens are collectively responsible for acts of violence against foreign nationals and should thus look for a morally sustainable solution to this evil. The article relies heavily on the work of Kristeva, entitled Strangers to Ourselves, and on the work of Nussbaum, entitled Ubuntu: Reflections of a South African on Our Common Humanity, in Reflections, the Society for Organizational Learning and the Massachusetts Institute of Technology.

\section{Introduction}

Undoubtedly, xenophobia and xenophobic attitudes are subjects of interest throughout the world today. The world is battling with addressing the problem of migration without being xenophobia. Europe and the United States are faced with the same challenge in terms of their relationship with Islamic countries in particular. Generally, xenophobic attitudes are a result of a struggle for scarce resources which citizens believe they have more rights to than foreigners. In South Africa, xenophobia manifests itself through negative attitudes and violence against non-nationals from other parts of Africa, a phenomenon now popularly referred to as 'Afrophobia'. Afrophobia signifies the idea that targets for violent attacks are black people suspected or known to be outsiders, particularly Africans such as Zimbabweans, Mozambicans, Somalis, Sudanese and lately Nigerians. In Europe (particularly the right wing of Europe) and the United States (perhaps it is right to speak of 'Trumpism' as a term that refers to US President Donald Trump's project to institute policies against Islamic States), it manifests itself through fear of Muslims popularly known as Islamophobia. Sundstrom (2013:69) argues that 'foreigner hatred and foreigner fear is embraced in Europe and the Unites States'. To justify his argument, he refers to a declaration from the organisation called 'Stop Islamisation of Europe' (i.e. SIOE) which states that ' $[r]$ acism is the lowest form of human stupidity, but Islamophobia is the height of common sense'. On the one hand, racism is condemned as immoral but, on the other hand, Islamophobia is moral.

Existing literature on xenophobia remains focused more on the causes thereof and only on the political dimension and not on the moral implication of the issue (e.g. Bealey 1999; Boaduo, Milondzo \& Adjei 2009; Landau 2011a; 2011b; Mafukata 2015; Nyamnjoh 2006; Nyar 2011; Phiri 2014). This article in contrast seeks to address the problem from the different perspective of its ethical outlook, drawing on two major values from the disciplines of philosophy and theology. The question I ask is: Why is xenophobia immoral? The article further seeks to indicate the attitude xenophobes ought to adopt if they want to be upright.

\section{Barbara Nussbaum (2003) captures the underlying Ubuntu ethic as follows:}

Ubuntu is the capacity in African culture to express compassion, reciprocity, dignity, harmony, and humanity in the interests of building and maintaining community. Ubuntu calls on us to believe and feel that: Your pain is my pain, my wealth is your wealth, and your salvation is my salvation. In essence, Ubuntu, an Nguni word from South Africa, addresses our interconnectedness, our common humanity, and the responsibility to each other that flows from our connection. The eclipse of Ubuntu 
has darkened the spirit of modern-day African political systems. However, imagine the potential of Ubuntu's sunlight, were it to be embraced as a vital part of the African renaissance or even as Africa's contribution to help a divided, fragmented world. (p. 21)

This captures ideals of what Ubuntu philosophy advocates. This being the case, I am mindful of not idealising or romanticising Ubuntu, which should be avoided. In addition to Nussbaum's argument, Desmond Tutu (2000) describes Ubuntu as:

It is the essence of being human. It speaks of the fact that my humanity is caught up and is inextricably bound up in yours. I am human because I belong. It speaks about wholeness, it speaks about compassion. (p. 31)

A person with Ubuntu is welcoming, hospitable, warm and generous, and willing to share. Such people are open and available to others, are willing to be vulnerable, are affirming of others and do not feel threatened that others are able and good, for they have a proper self-assurance that comes from knowing that they belong in a greater whole. They know that they are diminished when others are humiliated, diminished when others are oppressed and diminished when others are treated as if they were less than who they are. The quality of Ubuntu gives people resilience, enabling them to survive and emerge still human despite all efforts to dehumanise them (Tutu 2000:31).

On the one hand, the Ubuntu ethic that I espouse is a broad one, which embraces or extends to all people, especially those in most need or the vulnerable. A more narrow view of Ubuntu accommodates only those closest to us or those we feel at ease with. In this way, the broader Ubuntu theory I adopt in this article is a moral one that is more plausible than the narrow approach for including an impartial dimension. Ubuntu according to Ramose (1999) is better understood in its hyphenated sense as 'be-ing'. It is this be-ing-with others in the form of hospitality that the article seeks to apply to the topic of xenophobia. A number of scholars elaborate on the ideals of Ubuntu, and among these are Bhengu (1996; 2006), Broodryk (2002), Sindane (1994), Shutte (1993), Letseka (2000; 2012; 2013), Mbigi and Maree (1995), Metz (2007), Mnyaka (2003), Mnyaka and Motlhabi (2009), More (2006), Nussbaum (2003), Ramose (1999; 2003a; 2003b) and Teffo (2002). On the other hand, I further advance an argument that the Gospel understanding of love advocated by Jesus (Lk 10:vv.30-37), in the form of agape and philia as demonstrated in the parable of the Good Samaritan, is a Christian theory that entails the rejection of xenophobia. I wish to agree with Collins for arguing that 'it is not easy to, nor is it legitimate to, reduce the ethical teaching of the New Testament to a single ethical view' (1974:240). The specific Christian worldview I follow in this article serves as a framework for moral thinking that is fashioned on the ideal of compassion. It provides for the ability to perceive life from the vantage point of Christ's command to love selflessly. This command to love selflessly is epitomised in the parable of the Good Samaritan, which demonstrates the new attitude towards a stranger. This in my view can be interpreted in simple terms as implying at least 'do no harm to the other'. I move on to demonstrate by using the parable of the Good Samaritan that in a victimised stranger, he (the Good Samaritan) recognised himself.

In this article, I will demonstrate that these two moralities (i.e. Ubuntu and Christianity) are prima facie plausible as accounts of leading a virtuous life and that they prescribe allowing foreigners into our own land to become part of us by participating fully. The article seeks to explore the idea of philoxenia as a sustainable solution to the problem of xenophobia, embracing the spirit of Ubuntu as well as the Christian value of love. Philoxenia is derived from the Greek term meaning love of a stranger.

There are four main sections of this article structured as follows: The first section deals with the problem statement, which clarifies the question posed and states that xenophobia is not merely a political problem, which can be resolved politically through documentation or by legal ways. Xenophobia in all its manifestations which include Afrophobia and Islamophobia is also immoral and needs to be addressed on an interpersonal level. The second section discusses Ubuntu way of life and draws from it the lessons that by adopting this worldview, people can learn to be better and learn to be compassionate towards strangers. The third section looks at biblical solutions to xenophobia. Texts from both the Old and New Testaments are cited as evidence that God required from (his) chosen people to be sympathetic towards strangers. I argue that God demanded a different attitude from the chosen people towards strangers. The fourth, I will apply Ubuntu, Christianity to xenophobia, further explaining what philoxenia is, and how these two ethical theories reject xenophobia in all its forms.

\section{Problem statement}

The South African Constitution of 1996 is hailed as one of the most liberal constitutions in the world. Indeed, liberal democracy prides itself on promoting the following values: equality, respect for diversity and differences, recognition of 'the other' and competition. However, the same values are problematic because they are not implemented in reality. Embedded in all these values are class and the struggle for limited resources. 'Equality' and equal opportunities as promoted in the Constitution are therefore elusive and vexed concepts which are difficult to put into practice. One of the founding principles of the South African Constitution, stated in its preamble, is that 'South Africa belongs to all who live in it'. This is a noble ideal which seeks to welcome everybody who comes to live or establish themselves in this country, and implies that South Africa cannot and does not tolerate xenophobia in any form. In South Africa, the dehumanisation inherent in xenophobia is manifested in a number of ways which could be classified as direct violence or indirect victimisation at a higher level. In his work, Kelman (1973:38) identifies dehumanisation primarily as denying others the following two aspects of human life: 'agency and communion'. 
The two dimensions of human life are described by Abele and Wojciszke (2007:751) broadly as agency, the interest of which is on the self, and communion which primarily has interest on the other person or on others in general. For Abele and Wojciszke, communion is characterised by close and secure relationships based on friendliness, empathy, trust and helpfulness. They further maintain that these elements are indispensable for survival among human beings.

Mafukata (2015) points out that one of the causes of xenophobic attitudes by South Africans is the perception that foreign nationals are involved in criminal actions and argues that teaching foreign nationals to avoid criminal behaviour is essential. It is important that Mafukata raises this problem, namely the 'criminality' of foreign nationals, because this is certainly one of the many reasons that concerns South Africans, as confirmed by what in Charman and Piper $(2012: 84,89)$ is referred to as national foreigners regarded by South Africans as 'criminal threat'. The idea of 'criminal threat' is a serious concern given the recent incidents in Pretoria and Johannesburg in February 2017. Therefore, the perception among some South Africans is that one contributing factor to these attacks is criminality of some foreign nationals. But one can ask the question: What about the criminality of local people; does that raise as much concern? Koenane and Maphunye (2015:91) in their title 'Afrophobia, moral and political disguises: Sepa leholo ke la moeti' suggest that it is not unusual to shift blame on to foreigners while failing to address our own problems as South Africans. Outside its Southern African context, More (2006:156) holds a view that Ubuntu is known as African communalism or African humanism. These authors challenge South Africans, in particular policy-makers, to adopt an immigration policy that deals effectively with scarce resources, in particular jobs that provide sufficient income. The violence that is based on the struggle for employment and limited resources seem to suggest that foreigners do not deserve. This situation is made worse by the fact that foreigners are also denied justice or protection under the law. Because of competition for limited resources, violence against foreign nationals (particularly black foreign nationals) has become increasingly common in South Africa.

According to Koenane (2013), the problem of xenophobia does not only affect black South Africans, white South Africans have also expressed their resentment that white migrants from Europe, the United States, Australia and elsewhere in the world come to South Africa and are able to buy property easily with their strong currencies and secure, highly paid jobs which white South Africans do not get. Economic inequality is both a political and moral issue. The issue of 'equal opportunities' is a serious problem which needs to be addressed. The fact that majority of black people live below the breadline is morally unacceptable in a country where a few are extremely rich. The fact that the gap between the poor and the rich is widening is a moral disgrace for a country with resources such as South Africa has. The moral significance of the economy is on how it touches human life and whether it dehumanises or dignifies people. In short, economic decisions have moral consequences for human life.

The following is an example of how high ranking individuals' negative comments drove their supporters to xenophobic acts. In April (2015), King Zwelithini ${ }^{1}$ (of the Zulu people) was recorded uttering the following statement:

We talk of people who do not want to listen, who do not want to work, who are thieves, child rapists, and house breakers. [...]. When foreigners look at them, they will let us exploit the nation of idiots. As I speak you find their unsightly goods hanging all over our shops, they dirty our streets. We cannot even recognise which shop is which, there are foreigners everywhere. I know it is harder for other politicians to challenge this because they are after their votes. Please forgive me, but this is my responsibility, I must talk, I cannot wait for five years to say this. Asking of the Zulu nation [...] I will not keep quiet when our country is led by people who have no opinion. It is time we say something. I ask our government to help us to fix our own problems, to help us find our solutions. We ask foreign nationals to pack their belongings and go back to their countries. (De Vos 2015:n.p.)

King Zwelithini's statement followed an earlier statement made by Billy Masetlha, where he attributes criminality to undocumented foreigners. Landau (2011a) summarises Masetlha's utterances as follows:

Approximately 90 per cent of foreign persons who are in the Republic of South Africa with fraudulent documents [...] are involved, in other crimes as well [...] it is quicker to charge these criminals for their false documentation and then to deport them than to pursue the long route in respect of the other crimes that are committed. (p. 10)

Landau (2011a) also quotes the late Joe Modise at the time he was the Minister of Defence saying:

As for crime, the army is helping the police to get rid of crime and violence in the county. However, what can we do? We have one million illegal immigrants in our country who commit crimes and who are mistaken by some people for South African citizens. This is the real problem. (p. 9)

The common factor in all these statements is that crime is attributed to foreign nationals. Statements like these indirectly incite, authorise and legitimise xenophobic attitudes towards minority foreign nationals - particularly those of African origin. Such sentiments send wrong messages as perpetrators of violent crimes against foreign nationals believe they have the support of some leaders. Ordinary people tend to listen and obey authority without questioning such utterances, and the behaviour these people engage in may entail great harm to those that are considered easy targets, that is, foreign nationals. These people act without seriously reflecting on the implications of their actions. Such behaviour is further encouraged by the fact that government has failed to punish acts of xenophobia. The above statements form part of what Koenane and Maphunye (2015) regard as 'political disguise(s)', arguing that South

1.It has not been established whether the King was proposing that foreigners must leave KwaZulu-Natal or the country, but what is clear is that his Majesty's message instigated violence not only in KwaZulu-Natal but even outside the province. 
Africa should devise some means of addressing its fundamental political problems. Political problems should find political solutions, and this applies throughout the world. In Koenane and Maphunye (2015:87), Pogge asserts that governments have a moral obligation and political responsibility to give such people refugee status in terms of international law to accept refugees. Taking this further, Kristeva (1991) argues:

If political regulations or legislation generally speaking define the manner in which we posit, modify, and eventually improve the status of foreigners, they are also make up of a vicious circle for it is with respect to law that foreigners exist. Indeed, without social group structured about a power base and provided with legislation, that externality represented by the foreigner and most often experienced as unfavourable or at least problematical would simply not exist. (p. 87)

There is an assumption among unemployed and poor South Africans that the absence of foreign nationals would mean better opportunities for themselves. In South Africa, xenophobia is mainly justified on the basis of unemployment and struggle for scarce resources, whereas in developed countries like Europe and the United States, it is mainly on the grounds of insecurity or terrorism. Among South African nationals, there are many who are convinced that they are more deserving than foreign nationals. In Europe and the United States, the justification for exclusion particularly of Muslims is based on the threat of violence. As noted that the assumption of South Africans is based on a false assumption, the same applies in Europe and the United States that the absence of Muslims means that these citizens are safe and that there are no security threats while this is far from the truth. What leaders say is influential and has consequences. Clearly, there is a moral obligation for leaders to consider carefully the consequences of their public statements and take moral responsibility for them. Furthermore, leaders should be held accountable for their utterances, more so when such statements incite violence.

In her famous work entitled Strangers to Ourselves, Julia Kristeva (1991) asserts that individuals demonise the foreigner as a way of escaping from their own inherent 'strangeness' and suppressed dark nature. She believes the solution to this problem is the acknowledgement of our own hidden or 'uncanny strangeness,' Kristeva (1991) explicates:

Strangely, the foreigner lives within us, he [sic] is the hidden face of our identity, the space that wrecks our abode, the time in which our understanding and affinity founder. By recognizing him [sic] within ourselves, we are spared detesting him [sic] in himself [sic]. [...]. The foreigner comes in when the consciousness of my difference arises, and he [sic] disappears when we acknowledge ourselves as foreigners, unamenable to bonds and communities. (p. 2)

In the aforementioned statement in which Kristeva asserts that the stranger lives within us, the 'stranger' is our own shadow and it is only through recognising this that we are able to deal with that which we despise as 'other'. It is in this spirit the article interrogates the question: What is it like to be a foreigner or treated like one? This question should not be taken lightly, because it involved emotions, feelings and further questions one's identity. Basically, xenophobia in all its manifestations expresses an attitude that one does not 'belong'. Kristeva's sentiments are clearly expressed in the parable of the Good Samaritan who sees himself in the beaten and wounded victim left for dead. In other words, we are called to see ourselves in victims of xenophobia. This accords with the Ubuntu worldview which affirms that the importance we give to each other is what enables us to live together and respect our differences as human beings. Further, Ubuntu prides itself on seeing 'the other' as a true reflection of who oneself is. In other words, the self is, as Kristeva suggests, hidden in 'the other'. Landau (2011b) supports Ubuntu ideals and states as follows:

While the emphasis on a just and caring society reflects an implicit criticism of capitalism's inhumanity, [...], Ubuntu's action plan - helps shroud a demon: to create national cohesion means to overcome difference in a country which, if nothing else, is characterised by difference. (p. 229)

Deducing from Landau's statement cited above, I argue that difference need not translate to opposition. Mbembe and Rendall (2002) argue that the rehabilitation of Africa requires complete deconstruction of the idea of difference. Thakur (2011) contends that this deconstruction could come about by 'renouncing of self', which he argues is precondition of erasure of 'other'. Unfortunately, the ideals of Ubuntu are completely compromised in the name of patriotism and nationalism.

This is presented differently in the Bible's instruction to 'Love thy neighbour as thyself' (Matthew 22: v.40, NRSV). Put differently, for Kristeva, recognition of the self in the stranger proceeds from the proposition of an ontological ethical notion of the other as a 'hidden self'. Gula (1989:179) puts it differently: 'not until the other becomes incorporated into myself am I able to love God'. The 'other' should be recognised as the relational-self-identity. What makes recognising the self in relation to the other difficult is explained by Taylor (1994):

It is held that since 1492 Europeans have projected an image of such people as somehow inferior, 'uncivilized' and through the force of conquest have often been able to impose this image on the conquered. (p. 26)

It is my view that one of the evils of the apartheid system was its policy of dividing people and conditioning them into seeing differences in the other whom they regarded as inferior, thus victimising the vulnerable. This validates Biko's profound statement: '[T] he most powerful weapon in the hands of the oppressor is the mind of the oppressed' (Biko 1978:68). This statement indicates the power of the mind in the human psyche. Regarding the psychology of how we as human beings treat others, Taylor (1994) elucidates:

[...] our identity is partly shaped by recognition or its absence, often by the misrecognition of others, and so a person or group of people can suffer real damage, real distortion, if the people or society around them mirrors back to them a confining or demeaning $[\ldots]$ view of themselves. (p. 25) 
Taylor's assertion directly or indirectly supports Kristeva's argument that the stranger lives in the self. Further, Taylor's multiculturalism contributes to a better understanding of the importance of cultural differences. When contextualising xenophobia in South Africa, it is evident that through the policy of dividing Africans (black people), the apartheid system did more damage than we are ever able to undo. Kristeva (1991:97) further argues that as much as certain groups whose philosophy is based on Stoicism and the Judeo-Christian religion have offered some equal status and equal rights to foreigners, these are only realistic in the spiritual city because another set of rules is created to exclude foreigners from benefiting from the country's resources. This strengthens my argument that xenophobia is more than just a political attitude, and it is the politics of exclusion, victimisation and thus a moral challenge.

\section{Ubuntu worldview}

In traditional African societies, people lived their lives in accordance with certain botho or Ubuntu principles of which the key elements are summarised as follows: love, compassion, kindness, caring, generosity and sharing. In principle, botho or Ubuntu is the art of 'becoming'. The 'becoming' in which botho or Ubuntu principles and values are grounded encourages loving and caring more especially for the vulnerable (in this case foreigners). According to Mnyaka (2003:215), Ubuntu is 'an old philosophy of life that has sustained African communities together in South Africa'.

The maxim within which the botho or Ubuntu way of life is structured is manifested through doing good for others and treating them well. In a sense, Ubuntu is about adopting a new, positive attitude towards the other. Mnyaka and Motlhabi (2009:75) puts it thus: 'Ubuntu is the source or basis of feelings of compassion responsible for making life more humane for others, in particular the [...], as well as strangers'. In other words, embracing attitudes of loving and caring for others are values by means of which individuals are judged. Further, Ubuntu or botho values also manifest themselves in generosity and sharing with others. This sharing is unconditional and without limits. Therefore, insofar as the principle of Ubuntu or botho goes, the known definition of xenophobia is a misnomer. According to the Ubuntu or botho way of life, strangers are not a threat at all. Internalising Ubuntu or botho values means that individuals and their communities are encouraged to perform good actions. Following Ubuntu or botho principles implies that our humanness is measured by our interaction with others and strangers. Making strangers feel as though they belong is how people express botho or Ubuntu. Letseka (2000) explicates:

[...] Ubuntu has normative implications in that it encapsulates moral norms and values such as altruism, kindness, generosity, compassion, benevolence, courtesy and respect and concern for others. (p. 180)

The 'other' or 'others' is another human being or human beings, according to Levinas (1947:38). Letseka further articulates that the hallmark of people living in botho or Ubuntu communities is treating others (in the case of this article, foreigners) with a sense of botho (2000:188). I agree with Letseka, given that it was established that botho or Ubuntu is manifested in one's interaction with others. Among Africans, according to Koenane (2014), the unwritten law of hospitality, which is internalised always, has a binding force. The next section looks at the Holy Scriptures to further explicate the attitude God's chosen people should adopt towards strangers. Elsewhere Letseka (2013) views it thus:

Eventually, I offer my readers African traditional education and the Basotho indigenous education as programmes we might draw onto to address the development of the sort of personhood that is necessary for Ubuntu moral disposition. [...]. I surmised that young people who are initiated into Ubuntu morality have the potential to become citizens that are inclined to treating others with fairness at all times. (p. 351)

Both the Bible (as the expression of the Christian worldview) and Ubuntu worldview are regarded as potential positive attitudes changing worldviews that should be emphasised early on in our education system.

\section{The stranger in the Bible}

The Old Testament and the New Testament clearly portray God as the God who protects the foreigner. This is basically referred to as Judeo-Christian religion. As I indicated earlier in the abstract, Judaeo-Christian religion refers to common foundations of both Judaism and Christianity without giving too much emphasis on one at the expense of the other. God's message for his people becomes important not only for those who migrate and move but also, more importantly, for those who welcome or share warmth with strangers. This is not surprising because God always sides with the oppressed, as demonstrated by a number of biblical texts. The Old Testament, for example, Exodus 22:v.20 reads: 'You shall neither mistreat a stranger, nor oppress him, for you were strangers in the land of Egypt'. The idea of 'for you were strangers in the land of Egypt' suggests that this world is a homeland for all, as well as that all of us are strangers in this world. One of the many ways through which God tested the strength of the Israelites' loyalty was by their treatment of those classified as strangers. Exodus 22:v.23 goes on to read: 'they will surely cry out to me, and be sure I shall hear their cry; my anger will flare $[\ldots]$ '. This shows whose side is God on. Treating the stranger with malevolence is what made God take his side. Mistreatment of foreign nationals manifests itself in diverse ways including brutal violence. I would argue that the text cited above should be regarded as a moral instruction for the treatment of strangers, a moral law which God gave to his people and which they must obey or face his wrath.

The extreme level at which violence is manifested in South Africa has led to some arguing that violence is embedded in South African culture. For example, Vorster (2013:2) writes 'Violence has become a culture and is currently deeply embedded in the South African psyche'. Xenophobia in its 
Afrophobic form expressed in violent behaviour is perhaps understandable in socio-psychological and political terms. Foreign nationals are perceived as a separate category of people to be excluded from the country's resources which, it is believed, should only benefit South Africans. Obviously, this view contradicts those of scholars like Kristeva, 1991; Kelman 1973; and Taylor, 1994 and further goes against biblical precepts and Judeo-Christian moral values.

The Judeo-Christian principles encouraged values that govern against self-interested love and promoted the awareness that other people deserve to be treated with friendliness and empathy. This moral principle discouraged intolerance and promoted tolerance of other people. Xenophobia is intolerance of foreigners, whereas philoxenia is regarded as tolerance for strangers.

\section{The biblical solution to xenophobia}

This article argues that the Old Testament teaches us that God tested the loyalty of the Israelites by their attitudes towards a stranger and that mistreating a stranger was forbidden. God wanted the Israelites to remember their past when they too were strangers in Egypt and to recognise themselves in strangers. Phiri (2014:v) states in his study that being religious or Christian does not prevent an individual from having a xenophobic attitude towards those perceived to be foreigners. Given Phiri's observation, the question is: How can Christians respond in a way that reflects Christ's attitude towards xenophobia? On the other hand, taking this further, Mnyaka (2003:158) argues that it is from an outsider' perspective that Nguni people gather to mobilise their xenophobic attitude. This question is important because Christians are called upon to act in one way or another towards all forms of injustice: they cannot be indifferent towards the challenge of xenophobia. Failing to act is morally unacceptable for those who profess Christianity.

To answer this question, once again I turn to two main messages of the New Testament or the teachings of Christ. The first of these two messages is constructed in the form of the 'golden rule' in Matthew 1:v.12, which reads thus: 'In everything, do to others as you would have them do to you; for this is the law and the prophets' (The Holy Bible 1989). Certainly, there is no person who would wish for themselves the brutality and violence or mistreatment which foreigners are subjected to. Another scriptural text that comes to mind is the idea of 'loving thy neighbour as yourself' (Matthew 22:v.39) (The Holy Bible 1989). According to Kristeva (1991), the self is hidden in the stranger, so, if this is true, the text in Matthew 22:v.39 could be modified as follows: 'love the foreigner who is in yourself'. According to Matthew in the cited text, this is the second commandment; therefore, this is in a sense a moral imperative. I argue that accepting something as a moral imperative suggests that it is also morally binding. Recognising the stranger within ourselves is a means of gaining a better understanding of ourselves as strangers as well. Loving one's neighbour is equated with self-love. Stylianos (2000) articulates:

Therefore, the notion of the stranger and the foreigner takes on other dimensions and another quality in Christianity, Now the stranger is by definition every human being. And the most official stranger is God incarnate himself. (p. 11)

This takes us back to one of the earlier questions posed regarding the Christian's response to xenophobia in all its manifestations. Christians are instructed in the Bible to avoid mistreating and oppressing a stranger. Christ commanded his followers to treat others as they would want to be treated themselves. Every person would want to be treated with courtesy, compassion and kindness. Christ's law is simple and suggests that these are the values by means of which, as his followers, we ought to treat others. Gula (1989:179) takes this further. Although he accepts that the New Testament word for love is agape, he is also of the view that this Greek concept does not work for many people these days, for him the useful concept is 'hospitality'. For Gula, 'hospitality' seems to demand much more than just love, this is ideally the framework within which Christian love is better expressed. This is not all, in the beatitudes Jesus suggests that before God the way an individual treated a stranger would be the measure that will decide a person's fate (Matthew 25:35-36); the important words applicable in this article is as follows: 'when I was a stranger, you welcomed me', this is a serious message for a Christian.

Since xenophobic attitudes are learned, Mnyaka (2003) posits that it is vitally important to educate people about the evils of xenophobia. This, in his view, will help to curb xenophobic attitudes among South Africans.

Further, the biblical message from God to his people strongly emphasises the love of God, which according to St John is expressed in loving one's neighbour. St John puts it in an uncompromising way by suggesting that anyone who says they love God whom they cannot see, and fails to love the neighbour whom they live with and can see, are liars, (1 John 20-21). In fact, Hebrews 13:1-2 is very direct about the compassion which should be given to strangers, reading: 'Let brotherly love continue. Do not neglect to show hospitality to strangers, for thereby some have entertained angels unaware'. This text presents the stranger as a sacred being - an angel, this therefore suggests that in certain circumstances some strangers were angels. Compassion is the message Christ emphatically puts across in the parable of the Good Samaritan. The Good Samaritan in Jesus' eyes acted with the highest morality, by displaying compassion and love for this stranger. The compassion of the Good Samaritan is reflected in his identification with the suffering of this vulnerable stranger. The parable of the Good Samaritan culminates a moral obligation that God demands of his people. A moral commitment to address xenophobia with the intensity it deserves is yet to be seen in South Africa and the world beyond. Insofar as the parable of the Good Samaritan is concerned, compassion is measured by how well it is extended to the stranger. 


\section{Applying Ubuntu and Christianity to xenophobia}

This section focuses on the application of Ubuntu as the philosophy of life and Christianity, both of which guide relationships between strangers and locals. The Constitution of South Africa of 1996 provides that people should not be unfairly discriminated against. I am sure this is one of the principles of Ubuntu. Viewed carefully, it is apparent that the Ubuntu way of life and values are spiritually and ontologically embedded. In Koenane and Olatunji (2017), Stubbs draws similarities between Ubuntu values and Christianity, Teffo (2002:138) sees Ubuntu as the possession of inner quality 'that makes human person humane'. This being the case he further argues that the absence of this quality makes a person nonhuman. Mnyandu (1997) takes Teffo's argument further by arguing:

Ubuntu is not merely positive human qualities, but the very human essence itself, which lures and enables human beings to become abantu or humanised beings. Living in daily selfexpression works of love and effort to create harmonious relationships in the community and the world beyond. (p. 81)

This suggests that Ubuntu is achieved through demonstrating qualities that makes a person humane. This Menkiti takes further by arguing that people do not acquire personhood, in his view personhood is earned (1984:173). Taking this further one could argue that certain actions are uncharacteristic and thus not ideal to qualify one to be a person in the Menkitian sense.

Interestingly, Nussbaum argues for the implications of Ubuntu in the context of individuals and collective. She further avers that the spirit of Ubuntu could influence change in relationships. The issue of collective guilt is not an easy one to deal with. Frequently we hear people say they cannot take responsibility or be held accountable for what they did not personally do. However, from both Ubuntu and Christian perspectives, the idea of community as basis which form the foundations on which principles of becoming are established, collective guilt is not far-fetched. The implications of statements like this need to be interrogated for their sociomoral significance. Looked at from a Christian moralist viewpoint, nationalist prejudice(s) should arguably attribute a collective guilt to the nation at large. I argue that current ways in which xenophobia in its Afrophobic form is managed or mismanaged goes against both Ubuntu and Christian moral theories.

Espousing the theory of collective guilt and collective moral responsibility, the work of Verwoerd seems convincing. Verwoerd (2001:219) argues that moral guilt extends in varying degrees to those who did not necessarily participate in apartheid acts of human rights violations directly. This could be argued from a number of perspectives, but limiting myself to Verwoerd's position, he argues that by voting for the apartheid government Afrikaners who never personally committed these atrocities are guilty of the same crimes committed by the government they supported. In other words, some violations are committed by certain individuals in the name of the entire group. Hill (1984) puts it thus:

[...] a group may only be held responsible for the particular [human rights violations] of its members in so far as its other members enforce or $[\ldots]$ consent to them or condone them which of course they easily do. (p. 71)

I understand both Verwoerd and Hill to be arguing that from a Christian viewpoint, moral responsibility extends much further than their personal lives. As Christians, the human rights violations committed in our name by the groups or societies we belong to make all concerned, as Verwoerd (2001:219) argues, to some degree morally guilty. Therefore, as Christians called to act against all kinds of dehumanisation of others, we are equally morally guilty and responsible, from a Christian perspective. Aristotle (1990) differentiates between two kinds of acts: acts of commission and acts of omission. Clearly, for Aristotle, acts of commission are acts which a person performs directly, whereas acts of omission comprise of failing to act when one should have acted (Nicomachean Ethics 1990:1104b, 14-16).

\section{Conclusion}

This article challenges the traditional definition of xenophobia and argues that xenophobia in its Afrophobic manifestations, which include brutality and violence against African foreign nationals, goes much further than mere dislike for strangers. In addition, it points out that xenophobia in all its manifestations is a learnt attitude. This implies that it may be unlearned and replaced with a different attitude which could fundamentally alter the nature of interactions between local and foreign people.

Kristeva's metaphor of 'strangers to ourselves' is used to understand that recognising the stranger within ourselves helps in accepting the stranger who is the 'other'. Kristeva uses the concept of 'a stranger is the hidden self'. This was also demonstrated in terms of the parable of the Good Samaritan, who recognised himself in the victimised stranger. Jesus' parable of the Good Samaritan is an example of what compassion entails when extended to the stranger. I contend that certain leaders' statements, such as those that were cited in this article, have implications for what their followers do. Alternative attitudes towards national foreigners such as adopting Ubuntu principles and values could also be taught and internalised. Philoxenia, the principle of loving, caring and showing compassion to strangers as set out in the Bible, needs to be fostered at all levels of South African society. Taken together and independently, both Ubuntu principles and Christian values challenge human beings on how to treat vulnerable individuals (foreigners) in our society with kindness. Both these worldviews provide examples of how to be a better person in relation to foreigners.

\section{Acknowledgements Competing interests}

The author declares that he or she has no financial or personal relationships which may have inappropriately influenced him or her in writing this article. 


\section{References}

Abele, A.E. \& Wojciszke, B., 2007, 'Agency and communion from the perspective of self versus others', Journal of Personality and Social Psychology 93(5), 751-763. https://doi.org/10.1037/0022-3514.93.5.751

Aristotle, 1990, Nicomachean ethics, transl. D. Ross, Oxford University Press, Oxford.

Bealey, F., 1999, The Blackwell dictionary of political science, Blackwell Publishers, Oxford.

Bhengu, M.J., 1996, Ubuntu: The essence of democracy, Novalis Press, Cape Town.

Bhengu, M.J., 2006, Ubuntu: The global philosophy for humankind, Lotsha Publications, Cape Town.

Biko, S., 1978, I write what I like, Heinemann Publisher, London.

Boaduo, N.A.P, Milondzo K.S. \& Adjei, A., 2009, 'Genesis of peace education in an era of xenophobia and terrorism: The case of Africa', The Journal of Pan African Studies 2(9).

Broodryk, J., 2002, Ubuntu: Life lessons from Africa, Ubuntu School of Philosophy, Pretoria.

Charman, A. \& Piper, L., 2012, 'Xenophobia, criminality and violent entrepreneurship: Violence against Somali shopkeepers in Delft South, Cape Town, South Africa' South African Review of Sociology 43(3), 81-105. https://doi.org/10.1080/21528 586.2012.727550

De Vos, P., 2015, 'Xenophobia statement: Is King Zwelitini guilty of hate speech', viewed 16 August 2015, from http://constitutionallyspeaking.co.za/ xenophobicstatement-is-king-zwelithini-guilty-of-hate-speech/

Gula, R.M., 1989, Reason informed by faith: Foundations of catholic morality, Paulist Press, New York.

Hill, E., 1984, Being human: A biblical perspective, Geoffrey Chapman, London.

Kelman, H.C., 1973, 'Violence without moral restraint: Reflections on the dehumanization of victims and victimizers', Journal of Social Issues: A Journal of the Society for the Psychological Study of Social Issues 29(4), 25-61. https://doi. org/10.1111/j.1540-4560.1973.tb00102.x

Koenane, M.L.J., 2013, 'Xenophobic attacks in South Africa - An ethical response: Have we lost the underlying spirit of Ubuntu?', International Journal of Science, Commerce and Humanities 1(6), 106-111.

Koenane, M.L.J., 2014, 'Towards an ethical recontextualisation of Freud's theory of personality', Phronimon Journal of the South African Society for Greek Philosophy and the Humanities 15(1), 1-15.

Koenane, M.L.J. \& Maphunye, K.J., 2015, 'Afrophobia, moral and political disguises: Sepa leholo ke la moeti', Td: The Journal for Transdisciplinary Research in Southern Africa 11(4), 83-98. https://doi.org/10.4102/td.v11i4.45

Koenane, M.L.J. \& Olatunji, C.M.P., 2017, 'Is it the end or just the beginning of Ubuntu? Response to Matolino and Kwindingwi in view of Metz's rebuttal', South African Journal of Philosophy 36(2), 263-277. https://doi.org/10.1080/02580136.2016.1 225188

Kristeva, J., 1991, Strangers to ourselves, transl. L.S. Roudiez, Columbia University Press, New York.

Landau, L.B., 2011a, 'Introducing the demons', in L.B. Landau (ed.), Exorcising the demons within: Xenophobia, violence and statecraft in South Africa, pp. 1-26, Wits University Press, Johannesburg.

Landau, L.B., 2011b, 'Postscript: Positive values and the politics of outsiders', in L.B. Landau (ed.), Exorcising the demons within: Xenophobia, violence and statecraft in South Africa, pp. 226-236, Wits University Press, Johannesburg.

Letseka, M., 2000, 'African philosophy and educational discourse', in P. Higgs, N.C.G. Vakalisa, T.V. Mda \& N.T. Ansie-Lumumba (eds.), African voices in education, pp. 171-191, Juta, Cape Town.

Letseka, M., 2012, 'In defence of Ubuntu', Studies in Philosophy and Education 31, 47-60. https://doi.org/10.1007/s11217-011-9267-2

Letseka, M., 2013, 'Anchoring ubuntu morality', Mediterranean Journal of Social Sciences 4(3), 351-359. https://doi.org/10.5901/mjss.2013.v4n3p351

Levinas, E., 1947, Time and the other, transl. R. Cohen, Duquesne University Press, Pittsburgh, PA.

Mafukata, M.A., 2015, 'Xenophobia - The evil story of the beginning of fascism in post-apartheid South Africa', The International Journal of Humanities and Socia Studies 3(3), 30-44.
Mbembe, J. \& Rendall, S., 2002, 'African modes of self-writing', Public Culture 14(1), 239-273. https://doi.org/10.1215/08992363-14-1-239

Mbigi, L. \& Maree, J., 1995, Ubuntu: The spirit of African transformation management, Sigma Press, Johannesburg.

Menkiti, L.E., 1984, 'Person and community in African traditional thought', in R.A Wright (ed.), African philosophy: An introduction, pp. 171-181, University Press of America, Washington, DC

Metz, T., 2007, 'Towards an African moral theory', Journal of Political Philosophy 15(3), 321-341. https://doi.org/10.1111/j.1467-9760.2007.00280.x

Metz, T., 2011, 'Ubuntu as a moral theory and human rights in South Africa', African Human Rights Law Journal 11(2), 532-539.

Mnyaka, M.M.N., 2003, 'Xenophobia as a response to foreigners in post-apartheid South Africa and post-exilic Israel: A comparative critique in the light of the gospel and Ubuntu ethical principles', Unpublished doctoral thesis in the Subject Theological Ethics, University of South Africa, Pretoria.

Mnyaka, M.M.N. \& Motlhabi, M., 2009, 'Ubuntu and its socio-moral significance', in M.F. Murove (ed.), African ethics: An anthology of comparative and applied ethics, pp. 63-84. University of KwaZulu-Natal Press, Pietermaritzburg.

Mnyandu, M., 1997, 'Ubuntu as a basis for authentic humanity: An African perspective', Journal of Constructive Theology 3(1), 81.

More, M.P., 2006, 'Philosophy in South Africa under and after apartheid', in K. Wiredu (ed.), A companion to African philosophy, pp. 149-160, Blackwell Publishing, Hoboken, NJ.

Nussbaum, B., 2003, 'Ubuntu: Reflections of a South African on our common humanity, in reflections', Society for Organizational Learning and the Massachusetts Institute of Technology 4(4), 21-26.

Nyamnjoh, F.B., 2006, Insiders and outsiders: Citizenship and xenophobia in contemporary Southern Africa, CODESARIA Books in Association with Zed Books, Lontempon.
London

Nyar, A., 2011, What happened? A narrative of the May 2008 xenophobic violence, Gauteng City Region Observatory, Johannesburg.

Phiri, M., 2014, 'Xenophobia among young Christians with special reference to youth of the Fourways circuit Methodist Church of Southern Africa: An empirical exploration', Unpublished dissertation submitted for the degree Master of Theology at the University of South Africa, UNISA Press, Pretoria.

Ramose, M.B., 1999, African philosophy through Ubuntu, Mond Books Publishers, Harare.

Ramose, M.B., 2003a, 'The philosophy of Ubuntu and Ubuntu as a philosophy', in P.H. Coetzee \& A.P.J. Roux (eds.), Philosophy from Africa: A text with readings, pp. 230-238, Routledge Publishers, London.

Ramose, M.B., 2003b, 'The ethics of Ubuntu', in P.H. Coetzee \& A.P.J. Roux (eds.), Philosophy from Africa: A text with readings, pp. 324-330, Routledge Publishers, London.

Shutte, A., 1993, Philosophy for Africa, University of Cape Town Press, Rondebosch.

Sindane, J., 1994, Ubuntu and nation building, Ubuntu School of Philosophy, Pretoria.

Stylianos, H., 2000, 'Xenos and philoxenia in the Greek orthodox tradition', Phronema 15, 1-14.

Sundstrom, C., 2013, 'Facit and the displacement of mechanical calculators', IEEE Annals of the History of Computing 35(3), 20-31. https://doi.org/10.1109/ MAHC.2013.14

Taylor, C., 1994, 'The politics of recognition', in A. Gutmann (ed.), Multiculturalism, pp. 25-74, Princeton University Press, Princeton, NJ.

Teffo, L.J., 2002, 'Remaking Africa through a spiritual regeneration', in H.A.O. Mwakabana (ed.), Crises of life in African religion and Christianity, pp. 127-144, The Lutheran World Federation, Geneva.

Thakur, R., 2011. 'Delinking destiny from Geography: The changing balance of India-Pakistan Relations', India Quarterly: Journal of International Affairs 67(3), 197-112. https://doi.org/10.1177/097492841106700301

The Holy Bible, 1989, New revised standard version, catholic edition, Oxford University Press, New York.

Tutu, D.M., 2000, No future without forgiveness, DoubleDay, New York.

Verwoerd, W., 2001, 'On our moral responsibility for past violations', Alternation 8(1), 219-242.

Vorster, J.M., 2013, 'Dealing with violence in South Africa: The ethical responsibility of churches', Scriptura 112(1), 1-15. https://doi.org/10.7833/112-0-56 